\title{
Universal Access to Safe Drinking Water: Escaping the Traps of Non-Frugal Technologies
}

\author{
Zhe Huang ${ }^{1, *}$, Esther Laurentine Nya ${ }^{2}$, Viet Cao $\left.{ }^{3}{ }^{(}\right)$, Willis Gwenzi ${ }^{4} \oplus^{\circ}$, Mohammad Azizur Rahman ${ }^{5}$ \\ and Chicgoua Noubactep $6,7,8,9, *$ (1)
}

1 School of Law, Southeast University, Nanjing 211189, China

2 Faculty of Art, Letter and Social Sciences, University of Maroua, Maroua P.O. Box 644, Cameroon; nya.esther@yahoo.fr

3 Faculty of Natural Sciences, Hung Vuong University, Nguyen Tat Thanh Street, Viet Tri 35120, Phu Tho, Vietnam; caoviet@hvu.edu.vn

4 Biosystems and Environmental Engineering Research Group, Department of Agricultural and Biosystems Engineering, University of Zimbabwe, Mt. Pleasant, Harare P.O. Box MP167, Zimbabwe; wgwenzi@yahoo.co.uk 5 Technovative Solutions, Manchester Science Park, Manchester M15 6JJ, UK; aziz@technovativesolutions.co.uk

6 Centre for Modern Indian Studies (CeMIS), Universität Göttingen, Waldweg 26, D-37073 Göttingen, Germany

7 Applied Geology, University of Göttingen, Goldschmidtstraße 3, D-37077 Göttingen, Germany

8 Faculty of Health Sciences, Campus of Banekane, Université des Montagnes, Bangangté P.O. Box 208, Cameroon

9 School of Material Energy Water and Environmental Science (MEWES), Department of Water Environmental Science and Engineering (WESE), The Nelson Mandela African Institution of Science and Technology, Arusha P.O. Box 447, Tanzania

* Correspondence: maggie_huangzhe@126.com (Z.H.); cnoubac@gwdg.de (C.N.)

Citation: Huang, Z.; Nya, E.L.; Cao, V.; Gwenzi, W.; Rahman, M.A.; Noubactep, C. Universal Access to Safe Drinking Water: Escaping the Traps of Non-Frugal Technologies. Sustainability 2021, 13, 9645. https:// doi.org/10.3390/su13179645

Academic Editors: Alessio Siciliano and Marc A. Rosen

Received: 30 June 2021

Accepted: 22 August 2021

Published: 27 August 2021

Publisher's Note: MDPI stays neutral with regard to jurisdictional claims in published maps and institutional affiliations.

Copyright: (c) 2021 by the authors. Licensee MDPI, Basel, Switzerland. This article is an open access article distributed under the terms and conditions of the Creative Commons Attribution (CC BY) license (https:/ / creativecommons.org/licenses/by/ $4.0 /)$.
Abstract: This communication is motivated by recent publications discussing the affordability of appropriate decentralized solutions for safe drinking water provision in low-income communities. There is a huge contrast between the costs of presented technologies, which vary by a factor of up to 12. For example, for the production of $2000 \mathrm{~L} / \mathrm{d}$ of treated drinking water, the costs vary between about 1500 and 12,000 Euro. A closer look at the technologies reveals that expensive technologies use imported manufactured components or devices that cannot yet be locally produced. In the battle to achieve the United Nations Sustainable Development Goal for safe drinking water (SDG 6.1), such technologies should be, at best, considered as bridging solutions. For a sustainable self-reliance in safe drinking water supply, do-it-yourself (DIY) systems should be popularized. These DIY technologies include biochar and metallic iron $\left(\mathrm{Fe}^{0}\right)$ based systems. These relevant technologies should then be further improved through internal processes.

Keywords: appropriate technologies; cost-effectiveness; indigenous knowledge; point-of-use systems; self-reliance; water supply

\section{Introduction}

The international community has achieved the Millennium Development Goal 7C of halving the number of people without access to "improved" water supply by 2015 [1,2]. However, this success still leaves some 1.8 billion world citizens without safe drinking water, and 144 million continue to drink untreated surface water drawn from rivers or lakes $[3,4]$. It is hoped now, that through a synthesis of available knowledge and concerted research efforts, universal access to safe drinking water will be achieved by $2030[1,5,6]$.

The battle for a universal safe drinking water supply had started around 1950, when the world was divided into the following two groups: (i) the developed world with universal access to safe drinking water (and sanitation), and (ii) the developing world without proper access to safe drinking water, and a population prone to waterborne diseases [4,7]. It is rather surprising, that apart from China and a few countries who have significantly progressed since then, the situation remains unchanged 70 years later. This 
is certainly a reason to question the past and current approaches to clean drinking water supply. It should be recalled that sound principles for designing affordable systems for safe drinking water supply are documented in many old textbooks [8-10], review articles [11,12], and books on the history of water treatment $[7,13]$. In particular, the century-old textbook "An Elementary Handbook on Potable Water" [10] by Floyd Davis (1891) is very illustrative. Floyd Davis had already identified filtration using sand, animal charcoal (bone char), and wood charcoal as powerful tools to obtain high quality water for many purposes. However, while sand has been (to some extent) continuously used in water treatment plants [7], bone char has been outscored by other (re)active materials, including granular activated carbon (GAC). Bone char was almost independently re-discovered twice for water defluoridation: (i) during the 1930s as fluoride was established as a severe water pollutant [14,15], and (ii) during the late 1970s to solve the fluoride crisis in the developing world [16,17].

The main weakness of previous and current approaches can be traced to a paternalist way of thinking and doing. This approach regards the whole developing world as a burden for the developed world who has assigned itself the task to develop and transfer technologies to the rest of the world $[4,18,19]$. The notion of technology transfer and capacity-building as an approach to address problems in low-income countries is prevalent in water and sanitation and even public health, especially in Africa [20]. The fallacy of this approach is inherent to the Western elitist education system [21], and its wide adoption in the developing world [22,23]. In fact, even within the Western World, any knowledge shall be validated by universities. Using this approach, any other knowledge developed outside academia is often considered inferior and relegated to indigenous knowledge (systems), while some are still not validated by the academia. An example of this is rainwater harvesting $(\mathrm{RWH})$, which is the oldest form of water supply ubiquitous to every society [23-25] but is currently perceived as a new or recent technology [26-28].

While there is no problem with validating knowledge by experts, the problem arises when people in their natural environments are declared incompetent and condemned to wait for transferred technologies through capacity-building by external experts [21,26]. Moreover, even when more or less successfully transferred, there has been little capacity building, and the net result has been failure after the first technical problem $[18,19,29]$. The drinking water sector has not been an exception. In the past few decades, there has been an increasing interest for a participatory approach in introducing and disseminating new water treatment technologies [21,30-32]. This was characterized by terms such as "co-development", "knowledge democracy", "cognitive justice", and has culminated in empowering the people to be self-reliant in water supply [32-37]. In particular, Dr. Josh Kearns at North Carolina State University in the United States of America has developed an adaptable, modular, and transferable do-it-yourself technology-a biochar-based water filtration unit with capacity to produce up to $2000 \mathrm{~L} / \mathrm{d}$ that can be assembled in Thailand for less than 1500 Euro (www.aqsolutions.org, 25 May 2021). Moreover, this filtration technology addresses both microbial and chemical contamination. In fact, 1500 Euro corresponds more or less to the flight ticket of an expert from Europe to Thailand and is far less than the shipping cost of an expensive device for water treatment that dominates the current technology transfer paradigm [3,38].

This communication seeks to demonstrate that universal self-reliance in safe drinking water provision is possible using locally available materials, including gravel and sand, and the concept of the modular treatment train presented on YouTube by Aqueous Solutions (www.aqsolutions.org, 25 May 2021). "Aqueous Solutions" is a non-governmental organization (NGO) based in Thailand and in the United States of America (USA). The article presents two "co-development" technologies based on (i) biochar, and (ii) metallic iron $\left(\mathrm{Fe}^{0}\right)$. Both technologies have been intentionally developed during the past 15 years as DIY options. Furthermore, it is shown that $\mathrm{Fe}^{0}$-based units can be incorporated in the modular treatment train of Aqueous Solutions. The resulting technologies are discussed for their universal self-reliance application. Clearly, it is not only about the affordability of individual components, but the treatment chain as a whole. Research and development 
on such systems remains limited and is often just published as book chapters $[37,39,40]$ or academic dissertations [41-43].

The presentation will start with the methodology used for this communication, then the state-of-the-art knowledge on community-scale safe drinking water supply (Section 3). A selection of point-of-use water treatment systems and their estimated costs are then discussed.

\section{Methodology}

The literature research has not adapted any systematic approach for a literature review, for example, by using several search terms and combinations thereof to identify the scientific literature related to frugal systems for small-scale safe drinking water provision. The used references were rather selected for their suitability to address the subject based on two decades of active research on "decentralized safe drinking water supply". The communication is motivated by the following three key issues: (i) decentralized water supply systems are usually perceived as more costly than centralized systems, mostly due to a lack of consideration of the avoided costs, including the local manpower [44], (ii) many so-called innovative solutions are based on materials and principles that have been used for the same purposes for more than one century [10], and (iii) slow sand filtration (SSF) systems installed in European cities (e.g., Berlin, Paris) continue to operate today [45-47]. Early in the 20th century, SSFs lost their popularity, mostly because of the large space demand. SSFs were replaced by rapid sand filters (RSFs), which are coupled with chemical coagulation.

It is certain that the cost perspective widely depends on the stakeholder performing the economic analysis (e.g., developers, community of users, water agency) [44]. In this communication, cost comparison is based on a very recent cost analysis in a paper entitled "Economic evaluation of water supply systems operated with solar-driven electro-chlorination in rural regions in Nepal, Egypt and Tanzania" [3]. Covering three geographically distant countries, the analyses are practical and relevant for most of the situations in the developing world. The named cost evaluation [3] is also important because it addresses the relevance of subsidies by governments and international organizations in achieving "safe drinking water for all".

A great variety of safe drinking water supply technologies are available on the market $[3,31,47]$. Technological innovation continuously seeks to adapt or develop decentralized systems to the current needs of small communities [44]. Such technologies are usually developed at the niche level. Ideally, technological improvements should be directed at reducing maintenance requirements and reducing costs. New decentralized designs of water treatment should also be context-specific since system requirements differ significantly from place to place. All these criteria are important to select technology for the rural areas of developing countries where the procurement of materials is critical to achieve a sustainable water supply (Table 1).

Table 1. Main features of commercial and self-designed (frugal) decentralized safe drinking water supply systems.

\begin{tabular}{lll}
\hline Factor & Commercial Treatment Unit & Frugal Treatment System \\
\hline Participation & Very limited public participation & Active public participation \\
\hline Awareness & Citizens alienated from know-how & Citizens mastering the design and operation \\
\hline Funding & Highly subsidized & Mostly full cost recovery, and low-cost \\
\hline Resilience & Limited adaptation to changes & Enhanced adaptation to changes \\
\hline Social conflicts & More likely & Less likely \\
\hline Water quality & High for selected species & Adaptable and fit-for-purpose \\
\hline
\end{tabular}




\section{Community-Scale Safe Drinking Water Supply}

Decentralized systems for safe drinking water provision are an essential element in efforts to achieve Goal 6.1 of the Sustainable Development Goals of the United Nations ("drinking water for all"). This is mainly because centralized systems are non-existent in remote and scattered communities, mostly in developing countries $[2,48,49]$. The current paradigm considers that biological contamination is the most important problem in these communities due to the universal prevalence of pathogens [2,3,31,38]. Accordingly, a wide range of decentralized water treatment systems are available for water disinfection only. These include chemical (e.g., chlorination) [3], physical (e.g., filtration) [50,51], and thermal treatment methods (e.g., boiling, pasteurization) [29], and a combination thereof [40,52]. However, considering the increasing universal use of chemicals including those of emerging health concern (e.g., pharmaceuticals and personal care products), it has been recently demonstrated that contamination by synthetic chemicals is increasingly of worldwide concern $[32,53,54]$. This is in addition to well-known toxic geogenic contaminants such as radionuclides (e.g., U), arsenic, and fluoride, among others. Yet, current decentralized technologies for water treatment have a limited capacity to remove dissolved synthetic and geogenic contaminants [55]. For example, water disinfection by boiling may even increase the concentrations of toxic geogenic contaminants. Chlorination may generate human carcinogens in the presence of natural organic matter and has a limited capacity to remove dissolved contaminants. Consequently, decentralized safe drinking water systems should address both biological and chemical contamination [32,52,53]. Moreover, the quality of treated water should be assessed (or confirmed) using instrumental water analysis [54,56-58]. This calls for a shift in the present paradigm in developing countries that places emphasis on the water supply (e.g., via drilling of boreholes) with limited consideration for the analytical testing and treatment of such water. Excluding water testing and treatment in the water supply paradigm exposes humans to synthetic (e.g., pesticides) and geogenic contaminants (As, F, U). Thus, the need for the universal testing of drinking water has been discussed in a recent paper calling for the development of a water quality and quantity index (WQQI) [59]. Such a WQQI should be supported by the establishment of Water Applied Testing and Environmental Research (WATER) Centers [59]. Yet, most developing countries, including those in Africa, still lack the analytical infrastructure for the basic testing of drinking water.

The current presentation focuses on decentralized or point-of-use (POU) systems for safe drinking water provision at a community-scale. Household systems are excluded because monitoring their operation is very difficult [5,60-63]. However, the generic approach for the development of modular water treatment systems discussed here can be downscaled to the household level. Regarding appropriate water treatment technologies, important boundary conditions for the developing world include $[2,40,60]$ (i) robustness or consistency in performance, (ii) low implementation and running costs, (iii) ease of use and repair with no need for external special skilled personnel, (iv) ability to function without electricity (grid-independent), (v) based on local resources and skills, (vi) low maintenance, and (vii) should fit into the socio-cultural settings, including the capacity for women and girls to use and repair such technology. These conditions correspond largely to those of emergency water supply [63], with the subtle but essential difference that the population is available to co-design their own water treatment systems [19].

The modular treatment chain presented by Aqueous Solutions (www.aqsolutions.org, 25 May 2021), and the opportunity to independently replace individual treatment units (e.g., biochar filter, $\mathrm{Fe}^{0}$ /sand filter) almost eliminate the limitation of frequent and timeconsuming maintenance operations. For example, if the capacity of the biochar filter is exhausted, its replacement can be organized and operated in a few hours without disrupting the daily water supply. Note that, systems based on imported devices and components are explicitly excluded in the present discussion (Section 2). This excludes membrane technologies [51] and other robust systems that can be powered by solar energy (off grid) $[3,38,64]$. Chlorination and other chemistry-based water treatment methods 
are equally excluded due to their over-reliance on chemicals not readily available to communities.

This communication is not addressing the issue of water availability, but rather focuses on the treatment. There are various water sources depending on the geographic situation and some historical and cultural considerations. In principle, there are the following three sources of water for treatment: (i) rainwater, (ii) surface water, and (iii) groundwater [7]. As groundwater is present everywhere, the groundwater depth makes the difference, thus, borehole drilling can make water available [65]. It is considered that off-grid pumping (e.g., using solar or wind energy, and manual methods) will be used to pump water from wells into the storage tank and the rest of the system will be gravity driven [66]. According to the literature, water treatment trains comprising of biochar (BC) and/or metallic iron $\left(\mathrm{Fe}^{0}\right)$ are able to transform any polluted water into safe drinking water [32,34-36,52,53,55]. In other words, using natural geomaterials (e.g., gravel, pumice, sand), $\mathrm{BC}$ and $\mathrm{Fe}^{0}$ can provide safe drinking water everywhere. While Kearns and colleagues $[32,35,53]$ have developed and popularized tools to produce cost-effective BC everywhere, affordable $\mathrm{Fe}^{0}$ materials are also universally available, for example as steel wool [67-69].

The last important feature for the health of the community is water disinfection, in terms of preventing treated water being re-contaminated with pathogens $[2,63,70]$. The first thing to consider is that the universally used water chlorination is not safe [71-73]. This is particularly challenging under conditions where there is a lack of technical skills for proper dosage. Chlorination has been banned in The Netherlands in 2005 because of health issues [72,74], but is still recommended by the World Health Organization (WHO), especially in low-income countries lacking advanced water treatment technologies [3]. The question then arises: How do we cope with this issue and its potential human health risks? The answer is simple, this study is targeting small communities, where members can be educated to drink treated water within three days after treatment to avoid recontamination [60]. After this timeframe, treated water should be used for other purposes, including cooking. A viable alternative is the pasteurization of treated water twice or three times per week. This option is particularly recommendable where stored rainwater is the source of water. Solar pasteurization (SOPAS) can be used as a stand-alone water treatment technology where there is no chemical contamination. However, an affordable SOPAS for community water supply is yet to be designed $[66,75]$.

\section{Affordability and Sustainability of Selected Point-of-Use Water Treatment Systems}

Until now, the presentation has focused on POU systems as key solutions for safe drinking water provision in low-income communities (Section 3). Many POU systems have been developed and used in the last few decades; hence, this review gives an overview of the existing POU systems for small communities while insisting on those meeting the exclusion criteria (chemistry-free, grid-independent, locally available expertise, and materials). The aim is to recall the operating mode of relevant technologies and then discuss their affordability. Interested readers are referred to the abundant literature on POU systems for clean water in emergency situations [2,3] and for developing countries [63].

Table 2 presents a timeline of key events in the development and application of SSFs, particularly for small community water supply. In summary, as early as 1804, the efficiency of SSFs in water treatment was demonstrated in Scotland. Subsequent work conducted up to 1886 witnessed the applications of SSFs and $\mathrm{Fe}^{0}$-based systems for water treatment in a number of other countries including Belgium, Egypt, England, France, and India. Thereafter, SSFs, biological sand filters (BSFs), and Fe ${ }^{0}$-based water filtrations were developed almost independent of each other (Table 2). Biochar-based water filtration systems started to emerge around 2014 to 2017, following the work of Kearns et al. [35]. During the same period, the University of Idaho developed and patented N-E-W Tech ${ }^{\mathrm{TM}}$, a biochar-based reactive filter system (www.uidaho.edu/news/here-wehave-idaho-magazine/pastissues/2015-fall/greg-moller/, accessed on 29 July 2021). The $\mathrm{N}-\mathrm{E}-\mathrm{W}$ Tech ${ }^{\mathrm{TM}}$ is a high-flow system that can be adapted to have a throughput ranging 
from a few gallons per minute to tens of millions of gallons per day (www.uidaho.edu/ news/here-we-have-idaho-magazine/pastissues/2015-fall/greg-moller/, accessed on 29 July 2021). A subsequent seminal review further popularized biochar-based water filtrations as a sustainable and low-cost technology for drinking water supply in lowincome countries [55].

Table 2. Timeline of major events in the field of slow sand filtration (SSF) research and its adaptation to small community water supply.

\begin{tabular}{|c|c|c|}
\hline Anno & Event & Refs. \\
\hline 1804 & Demonstration of the efficiency of SSFs by John Gibb in Paisley (Scotland) & [10] \\
\hline 1829 & Adoption of SSFs for the water supply of Chelsea (London/England) & [10] \\
\hline 1881 & $\mathrm{Fe}^{0}$ amended SSFs for the water supply of Antwerp (Belgium) & {$[76]$} \\
\hline 1883 & $\mathrm{Fe}^{0}$-based revolving purifier for the water supply of Antwerp (Belgium) & [77] \\
\hline 1886 & SSFs demonstrated to remove bacteria by Frankland & [78] \\
\hline 1951 & Domestic steel wool water filters for radionuclides removal & [79] \\
\hline 1980s & Renewed interest in SSFs for small and medium communities & {$[45,47]$} \\
\hline 1985 & Schmutzdecke shown to remove coliforms by Bellamy & {$[45,47]$} \\
\hline 1992 & Down-scaling of SSFs for the domestic needs by David H. Manz (BSFs) & [80] \\
\hline $1990 \mathrm{~s}$ & Attempts to improve the efficiency of SSF by reinforcing biological activities & {$[81,82]$} \\
\hline 2000 & $\mathrm{Fe}^{0}$ amended BSFs for the As and pathogen removal in Bangladesh & [83] \\
\hline 2006 & Development of Kanchan Arsenic filters in Nepal & [84] \\
\hline 2007 & Development of SONO Arsenic filters in Bangladesh & [85] \\
\hline 2008 & Development of IITB Arsenic filters in West Bengal (India) & {$[37,40]$} \\
\hline 2010 & $\mathrm{Fe}^{0}$ amended BSFs for the As, pathogen, and U removal in rural Canada & [39] \\
\hline 2012 & Efficiency of Kanchan Arsenic filters disproved & [86] \\
\hline 2012 & Adoption of SSFs for the water supply in rural Switzerland & {$[87]$} \\
\hline$>2012$ & Implementation of several aggregate-amended SSFs for rural water supply & {$[52,88]$} \\
\hline 2016 & Development of the modular SSF/biochar filters for rural water supply & {$[35,89]$} \\
\hline 2019 & Domestic steel wool-based water filter operating for one year & {$[43,68]$} \\
\hline
\end{tabular}

Before presenting the technologies and discussing their costs, it is important to recall the key points related to clean water provision. Cities in developed countries are supplied with drinking water provided via conventional centralized water treatment systems. Centralized water supply systems are often owned by the municipalities or private organizations that are working on their behalf. Treated water is distributed to households via piping systems and citizens pay tax for drinking water and the resulting wastewater. Still, in the developed world, where the density of population is too low and the tax money cannot enable affordable safe drinking water, a decentralized water supply is organized and controlled [90-92]. This approach motivated the renewed interest for slow sand filters (SSFs) in the Western World during the 1980s (Table 2) [93]. Recently, Jepson and Vandewalle [92] maintained that the view that households in developed countries have universal piped indoor water is a pervasive one. In the United States, for example, more than 600,000 households must struggle daily for outdoor safe drinking water. The concerned mostly low-income rural communities (e.g., on the Texas-Mexico border) are regarded as "marginalized communities" with regard to access to safe drinking water. However, there are reliable programs to alleviate household water insecurity and the population largely has access to water of drinking quality at some reasonable distance from their homes. 
In developing countries, however, the upfront cost of centralized water treatment and distribution systems hinder their installation even in densely populated cities and peri-urban areas [3]. Moreover, due to weak governance systems and poor accountability, the taxes paid for water are often not invested back to improve water infrastructure. As a result, water infrastructure progressively deteriorates against a background of increasing water demands driven by rapid population growth and rural-urban migration. POU technologies are on-site water treatment systems that address this situation.

The relevant POU technologies are coagulation/flocculation, disinfection, and filtration $[3,8]$. Flocculation and coagulation use chemicals (non-chemistry-free) to remove the contaminants and turbidity. Disinfection kills pathogens by heating or the addition of chemicals. Heating can be achieved by firewood or fossil fuels. However, the current conventional disinfection methods such as chlorination are not chemical free, while the critical shortage of firewood and fossils fuels, and the associated costs, may constrain heating/boiling. From the three possible principles highlighted, only filtration remains as the candidate technology meeting the criteria. In other words, self-reliance in safe drinking water supply depends on the ability to design gravity-driven filtration systems capable of freeing polluted waters from biological, chemical, and physical contamination. Filtration basically removes contaminants by size exclusion, whereby particles and species larger than the pore size of the filter are retained within the system $[2,8,34,94,95]$.

The filtration technologies implemented at the POU are mainly slow sand filtration (SSF) and membrane filtration [3,51,63]. Membrane filtration is excluded herein because it is not always grid-independent, and in most low-income countries, membranes are not fabricated locally (Table 1). In other words, SSF and their modifications could transform polluted water to drinking water everywhere (Table 2). SSFs are easily constructed using raw materials that are locally sourced. Over the past few decades, the amendment of SSF with adsorbing (e.g., biochar, granular activated carbon, metal oxides) and reactive (e.g., $\mathrm{MnO}_{2}$, metallic iron) materials have improved their capacity at removing pathogens and various classes of chemical contaminants [34,52,55,96,97].

Since 2006, the research group of Dr. Noubactep (Göttingen, Germany) has been continuously working on ways and means to make $\mathrm{Fe}^{0}$-based systems a universal solution for decentralized safe drinking water provision [34,97]. The state-of-the-art knowledge is that filtration on $\mathrm{Fe}^{0}$ beds sandwiched between SSFs will eliminate all the naturally occurring contaminants except fluoride [98,99]. However, bone char is an affordable material of choice for fluoride removal [100] and the odors from the bone char filtration are eliminated by $\mathrm{Fe}^{0}$ filtration. Thus, a multiple barrier system comprising bone char, $\mathrm{Fe}^{0} /$ sand, and SSF, designed on a site-specific basis, can be developed for clean water production. A biochar barrier (BC unit) can be part of this treatment train. During the past 15 years, Kearns and colleagues have demonstrated the particular suitability of BC units to generate safe drinking water from organic- and pathogen-laden natural waters [32,35,42,53].

As a proponent of technology co-development, Dr. Josh Kearns has developed and published on YouTube a modular and adaptable water treatment train with translation in many languages. This demonstration is regarded by the authors as the key for universal selfreliance in safe drinking water provision. The evidence shows that in most cases, research laboratories at local universities in low-income countries have tested the suitability of most locally available materials (e.g., geomaterials, biomaterials) for the remediation of common contaminants in local water sources $[43,58]$. Thus, one just needs to replace the biochar unit in Figure 1 with a relevant locally available bio- or geo-material and test its operational efficiency and sustainability. If this approach is adopted immediately everywhere, there is no doubt, the Goal 6.1 of the UN SDGs will be achieved by 2030. 


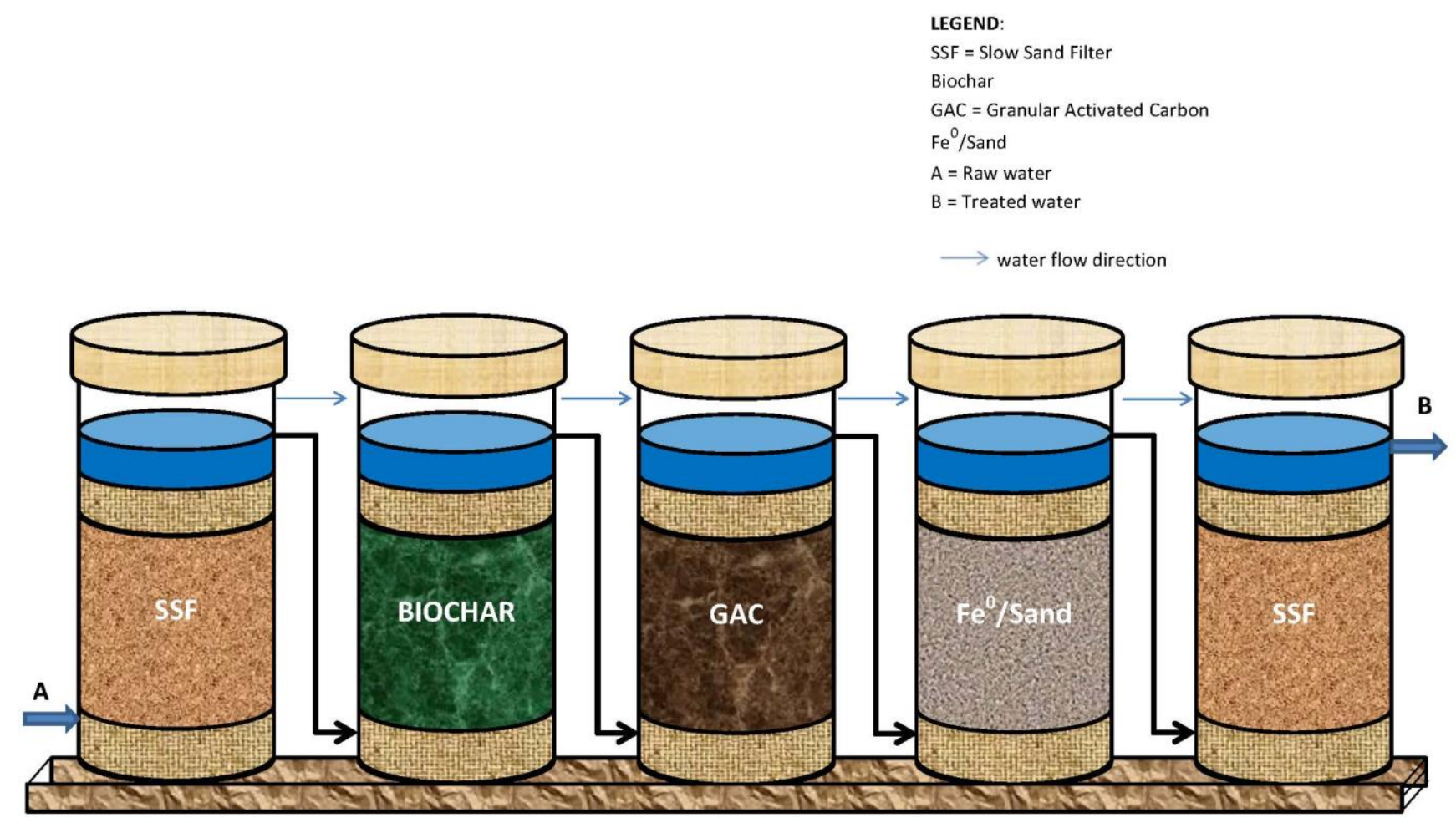

Figure 1. Possible water treatment train for a small-scale plant. Here, the following three units for the removal of chemicals are presented: biochar, granular activated carbon (GAC), and $\mathrm{Fe}^{0} /$ sand. The three units are sandwiched between two slow sand filters (SSFs). Water from the second SSF is stored for distribution.

A closer examination of the four technologies in Table 3 further shows several merits of biochar and $\mathrm{Fe}^{0}$ water filtration systems. Biochar and $\mathrm{Fe}^{0}$ have no or limited adverse effects on the taste of water, unlike chlorination. Biochars can be locally prepared using low-cost pyrolysis systems and readily available biomaterials. Chlorination has the potential to generate carcinogens in the presence of natural organic matter, a common constituent in most natural waters. Biochar and $\mathrm{Fe}^{0}$ filtration systems are gravity driven, and hence require biochar produced via pyrolysis using local and readily available feedstocks and materials (e.g., used drums, pit kilns, biochar cookstoves) [55,101]. Similarly, most lowincome countries in the Global South have large reserves of iron ore, hence $\mathrm{Fe}^{0}$ is readily available at a nominal cost. The proposed systems are less sophisticated than imported ones $[3,38,51]$; hence, they are easier to install and repair at a local level by community members including women and girls, without the need for external experts from faraway cities/towns and foreign countries. Due to these several merits, such technologies may fit the socio-economic settings in most low-income countries better than imported technologies $[18,19]$. Overall, the nominal cost of the proposed technology is several orders of magnitude lower than the several thousands of dollars used by NGOs and governments in effort to provide clean drinking water. Moreover, the proposed technology should be integrated into the water supply systems including cases where boreholes have been drilled in highly mineralized geological systems rich in toxic geogenic contaminants without addressing the water quality aspects. Taken together, the proposed point-of use treatment systems warrant pilot testing in low-income countries. 
Table 3. Comparison of investment, installation, and running costs for four small-scale water supply systems using (i) biochar, (ii) metallic iron $\left(\mathrm{Fe}^{0}\right)$, (iii) PAUL, and (iv) Autarcon (chlorination). All costs that are equal for all systems are operationally considered to be zero (available). The Autarcon system needs energy for in situ generation of chlorine and addresses only microbial contamination. PAUL stands for "Portable Aqua Unit for Lifesaving" and is a membrane-based technology producing up to $1200 \mathrm{~L} / \mathrm{d}$. One PAUL costs 1000 Euro, two are used to cope with the community water requirements $(2000 \mathrm{~L} / \mathrm{d})$.

\begin{tabular}{|c|c|c|c|c|}
\hline & Biochar & Metal Iron & PAUL & Autarcon \\
\hline & (Euro) & (Euro) & (Euro) & (Euro) \\
\hline Reference & [49] & [96] & [51] & [3] \\
\hline Water availability (e.g., well drilling) & 0.0 & 0.0 & 0.0 & 0.0 \\
\hline Building infrastructure & 0.0 & 0.0 & 0.0 & 0.0 \\
\hline Water pumping & 0.0 & 0.0 & 0.0 & 0.0 \\
\hline Water supply system & 0.0 & 0.0 & 0.0 & 0.0 \\
\hline Material cost $(\mathrm{O} \& \mathrm{M})$ & 1000 & 1250 & 0 & 13,500 \\
\hline Water treatment system (WTS) & 1500 & 2000 & 2000 & 12,000 \\
\hline Energy supply & 0 & 0 & 0 & 500 \\
\hline Installation (labor) & 0 & 0 & 0 & 3500 \\
\hline Operation and Maintenance (per year) & 0 & 0 & 0 & 1004 \\
\hline Transport of WTS & 0 & 0 & 200 & 1000 \\
\hline Customs duty & 0 & 0 & 100 & 3910 \\
\hline Spare parts (per year) & 0.0 & 0.0 & 0.0 & 917 \\
\hline Total costs & 2500 & 3250 & 2300 & 36,331 \\
\hline Ratio Autarcon/X & 14.5 & 11.2 & 15.8 & 1.0 \\
\hline
\end{tabular}

\section{Sand Filtration Systems: The Partly Overlooked Universal Solution}

The presentation until now can be regarded as a re-demonstration of the suitability of SSFs for water treatment at the small community level. This section reveals that this task has already been realized several times. It suffices to recall the history of slow sand filters (SSFs), biological sand filters (BSFs), and their amendment with various materials (Table 2) in the following four points

(i) Slow sand filters are considered as the oldest community-scale water treatment technology. The first SSF was demonstrated by John Gibb in 1804 in Paisley (Scotland). In 1829, a SSF was adopted for a public water supply at the Chelsea Water Company in London $[90,93,102-104]$. Since then, SSFs have been widely used in water treatment plants for the inactivation and removal of microorganisms [52,90]. However, SSFs alone will not be able to produce water that is free from bacteria and viruses. Therefore, further treatment such as disinfection is always needed. One ancient water disinfectant is metallic iron $\left(\mathrm{Fe}^{0}\right)[8,9]$.

(ii) SSFs amended with $\mathrm{Fe}^{0}$ ( $\mathrm{Fe}^{0} \mathrm{SSF}$ ) were used to successfully supply the city of Antwerp (Belgium) with safe drinking water from 1881 to 1883 [105]. The systems worked without maintenance for 18 months. At that time, the city of Antwerp then had 200,000 inhabitants. This means that supplying up to 200,000 people with safe drinking water from $\mathrm{Fe}^{0}$-amended filters is a 140 -year-old technology. Today, in most cases, the challenge is to supply some small communities with less than 20,000 inhabitants, 10 times lower that population of Antwerp in 1883. Clearly, $\mathrm{Fe}^{0} \mathrm{SSFs}$ can supply adequate clean drinking water to typical small communities.

(iii) In the early 1990s, Dr. David H. Manz developed a hypothesis that enabled the scaling down of SSFs and their adaptation to intermittent small community and household filters, termed as biological sand filters (BSFs) $[102,106,107]$. The effectiveness of BSFs in 
quantitatively removing fecal coliform indicators was then demonstrated, and the need of improved pathogen removal established. Similar to SSFs, $\mathrm{Fe}^{0}$-amended BSFs $\left(\mathrm{Fe}^{0} \mathrm{BSFs}\right)$ were proven efficient for safe drinking water provision [67]. During the past decade, experimental investigations have identified design and operation recommendations to improve the effectiveness of the next generation of $\mathrm{Fe}^{0}$-amended BSFs [68].

(iv) SSFs were abandoned in the early 20th century because their low hydraulic loading rate and large drinking water volumes required for large populations was only possible with large areas. This limitation has led to the adoption of rapid sand filters (RSFs) after coagulation and flocculation [7]. However, there is strictly no such land scarcity in the rural areas of developing countries for SSFs, meaning that the installation of SSFs is still an option in many cases. However, the relatively low drinking water demand can still be satisfied by community-scale BSFs. It is interesting to note that such filters are operating in the developed world, for example in rural Switzerland [108,109], pointing to the possibility to develop and implement similar systems in developing countries [99-110].

To summarize, SSFs and BSFs are affordable water treatment systems whose relatively high efficiency for pathogen removal is well-documented. However, their inefficiency for the removal of chemical contamination (e.g., synthetic organic substances, heavy metals) are known and well-documented. Both systems have been improved by amendment with other materials, including $\mathrm{Fe}^{0}$ [110]. The question arises, "why has the search for frugal solutions for safe drinking water not started by this universal solution?". There is no unique answer to this question, but it is time to retrace the steps to this simple technology, and start solving drinking problems, and achieve the Sustainable Development Goal 6.1 with the readily available means. Table 4 summarizes the capability of BC-and $\mathrm{Fe}^{0}$-amended SSFs for safe drinking water provision. The details of the removal efficiencies and mechanisms for specific types of dissolved organic and inorganic contaminants, pathogenic organisms, and suspended solids are given in the literature summarized in Table 2 . Hence, for brevity, these aspects are not repeated in the present paper. Here, only a summary of the performance is given. This recall is regarded as an appeal for any developer. The article advocates that any new development should be frugal and shall demonstrate how it surpasses these achievements.

Table 4. Comparison of the efficiency of slow sand filters (SSFs), single aggregate filters and two amended SSFs for the removal of chemicals, odors, and pathogens. + stands for low, ++ for good, and +++ for excellent. Efficient frugal water treatment systems are possible everywhere, as BC and $\mathrm{Fe}^{0}$ are universally affordable and available.

\begin{tabular}{ccccc}
\hline Technique & Expertise & \multicolumn{3}{c}{ Removal Efficiency for } \\
\hline (Years) & Chemicals & Odors & Pathogens \\
\hline SSF & 190 & + & ++ & ++ \\
\hline Fe $^{0}$ & $>160$ & ++ & +++ & +++ \\
\hline Biochar & 20 & +++ & +++ & ++ \\
\hline Bone char & $>160$ & +++ & +++ & ++ \\
\hline Fe $^{0}$ SSF & 150 & +++ & +++ & +++ \\
\hline BC SSF & 15 & +++ & +++ & +++ \\
\hline
\end{tabular}

\section{Conclusions}

An overview of the affordability and effectiveness of water treatment options to provide small communities with safe drinking water is given. Relevant water treatment options include chemical treatments (e.g., chlorination), ecological treatments (e.g., slow sand filtration), physical treatments (e.g., filtration), thermal treatments (e.g., heating, and ultraviolet radiation), and hybrid treatment chains (e.g., multiple barrier approach). The objective was to assess whether frugal (chemistry-free, electricity-free) technologies for selfreliance in safe drinking water supply are already available in the literature (Tables 2 and 4). 
The results indicate that the multiple barrier approach presented by Dr. Kearns is affordable and adaptable to any situation. The site-specific adaptation depends not only on the nature of polluted water but also from the available expertise. For example, a community that has expertise with GAC will preferentially replace the biochar unit (Figure 1) with a GAC unit, while a community with fluoride contamination will add a bone char or activated alumina unit. $\mathrm{Fe}^{0}$ /sand units can be added both for main treatment and for affinage, for example, in this case, fluoride free water from a bone char unit should be freed from odors [52].

This study shows how self-assembled community-scale water filtration devices can universally solve the long-lasting problem of unsanitary drinking water conditions. In the Global South in general and Africa and South East Asia in particular, a legitimized, longterm solution for "own" safe drinking water is presented (Table 4). In other words, two independent research groups one led by Dr. Josh Kearns working in Thailand and another by Prof. Chicgoua Noubactep conducting work in Cameroon/Tanzania have demonstrated the feasibility of self-reliant, small-scale water treatment systems during the last 15 years. These findings rapidly mitigate water insecurity worldwide $[32,35,42,50,53,98,99]$. Interestingly, such systems will find applications also in developed countries, for example in solving "chronic" household water insecurity in Texas/USA [70,92]. The large-scale field implementation of these findings is up to engineers, public health research scientists, and universities in the Global South who can best assess and address the local conditions of their residents. Of course, national and international NGOs can support these efforts. Scientists from other regions of the world can support these efforts. It should be explicitly said that any effort to continue the development of non-frugal technologies for the developing world is contra productive. It is definitively not worth the effort to design water treatment units for the Global South in which transport costs are more expensive than the installation of alternative units accomplishing the same task (Table 3). It is hoped that this communication opens an avenue for the achievement of Goal 6.1 of the SDGs, while inaugurating a new area for drinking water governance in the Global South.

Author Contributions: Conceptualization, C.N., Z.H. and W.G.; methodology, Z.H. and E.L.N.; formal analysis, Z.H., C.N. and W.G.; writing-original draft preparation, Z.H., C.N. and W.G.; writing-review and editing, E.L.N., V.C., M.A.R., Z.H., C.N. and W.G. All authors have read and agreed to the published version of the manuscript.

Funding: This research received no external funding.

Institutional Review Board Statement: Not applicable.

Informed Consent Statement: Not applicable.

Data Availability Statement: All data are included in the paper.

Acknowledgments: We would like to thank the peer reviewers for their valuable suggestions and comments on improving this paper. We acknowledge support by the German Research Foundation and the Open Access Publication Funds of the Göttingen University.

Conflicts of Interest: The authors declare no conflict of interest.

$\begin{array}{ll}\text { Abbreviations } \\ \text { BC } & \text { Biochar } \\ \mathrm{BSF}(\mathrm{s}) & \text { Biological sand filter(s) } \\ \mathrm{Fe}^{0} & \text { Metallic or zero-valent iron } \\ \mathrm{GAC} & \text { Granular activated carbon } \\ \text { RWH } & \text { Rainwater harvesting } \\ \mathrm{NGO} & \text { Non-governmental organization } \\ \mathrm{O} \& \mathrm{M} & \text { Operation and maintenance } \\ \text { POU } & \text { Point-of-use } \\ \text { RSF(s) } & \text { Rapid sand filter(s) }\end{array}$




$\begin{array}{ll}\text { SDG } & \text { Sustainable Development Goal } \\ \text { SOPAS } & \text { Solar pasteurization } \\ \text { SSF(s) } & \text { Slow sand filter(s) } \\ \text { WATER } & \text { Water Applied Testing and Environmental Research } \\ \text { WQQI } & \text { Water Quality and Quantity Index } \\ \text { WTS } & \text { Water treatment system }\end{array}$

\section{References}

1. Hering, J.G.; Maag, S.; Schnoor, J.L. A call for synthesis of water research to achieve the sustainable development goals by 2030. Environ. Sci. Technol. 2016, 50, 6122-6123. [CrossRef]

2. Pooi, C.K.; Ng, H.Y. Review of low-cost point-of-use water treatment systems for developing communities. NPJ Clean Water 2018, 1, 11. [CrossRef]

3. Otter, P.; Sattler, W.; Grischek, T.; Jaskolski, M.; Mey, E.; Ulmer, N.; Grossmann, P.; Matthias, F.; Malakarh, P.; Goldmaier, A.; et al. Economic evaluation of water supply systems operated with solar-driven electro-chlorination in rural regions in Nepal, Egypt and Tanzania. Water Res. 2020, 187, 116384. [CrossRef]

4. Halvorson, S.J.; Wescoat, J.L., Jr. Guarding the sons of empire: Military-state-society relations in water, sanitation and health programs of mid-19th-century India. Water 2020, 12, 429. [CrossRef]

5. Cao, V.; Yang, H.; Ndé-Tchoupé, A.I.; Hu, R.; Gwenzi, W.; Noubactep, C. Tracing the scientific history of Fe ${ }^{0}$-based environmental remediation prior to the advent of permeable reactive barriers. Processes 2020, 8, 977. [CrossRef]

6. Masten, S.J.; Harris, A.; Kearns, J.; Borrion, A.; Peters, C.A.; Gadhamshetty, V.R. Special issue: Global environmental engineering for and with historically marginalized communities. Environ. Eng. Sci. 2021, 38, 285-287. [CrossRef] [PubMed]

7. Howe, K.J.; Hand, D.W.; Crittenden, J.C.; Trussell, R.R.; Tchobanoglous, G. Principles of Water Treatment; John Wiley \& Sons, Inc.: Hoboken, NJ, USA, 2012; 674p.

8. Nichols, W.R. Water Supply, Considered Mainly from a Chemical and Sanitary Standpoint; John Wiley \& Sons: New York, NY, USA, 1883; 260p.

9. Slater, J.W. Sewage Treatment Purification and Utilization; Whittaker \& Co.: London, UK; New York, NY, USA, 1888; 320p.

10. Davis, F. An Elementary Handbook on Potable Water; Silver, Burdett \& Co.: New York, NY, USA; Boston, MA, USA; Chicago, IL, USA, 1891; 118p.

11. Tucker, W.G. The purification of water by chemical treatment. Science 1892, 20, 34-38. [CrossRef] [PubMed]

12. Baker, M.N. Sketch of the history of water treatment. J. Am. Water Works Assoc. 1934, 26, 902-938. [CrossRef]

13. Hamlin, C. A Science of Impurity: Water Analysis in Nineteenth Century Britain; University of California Press: Berkeley, CA, USA, 1990.

14. Boruff, C.S. Removal of fluoride from drinking waters. Ind. Eng. Chem. 1936, 26, 69-71. [CrossRef]

15. Smith, H.V.; Davey, W.B. The development and use of the bone filter for removing fluoride from drinking water. Univ. Ariz. Agric. Exp. Stn. Tech. Bull. 1939, 81, 249-292.

16. Fewtrell, L.; Smith, S.; Kay, D.; Bartram, J. An attempt to estimate the global burden of disease due to fluoride in drinking water. J. Water Health 2006, 4, 533-542. [CrossRef]

17. Brunson, L.R.; Sabatini, D.A. An evaluation of fish bone char as an appropriate arsenic and fluoride removal technology for emerging regions. Environ. Eng. Sci. 2009, 26, 1777-1784. [CrossRef]

18. Schumacher, E.F. Small Is Beautiful: Economics as if People Mattered; Harper \& Row: New York, NY, USA, 1973; 324p.

19. Roy, B.; Hartigan, J. Empowering the rural poor to develop themselves: The barefoot approach. Innovations 2008, 3, 67-93. [CrossRef]

20. Gwenzi, W.; Rzymski, P. When silence goes viral, Africa sneezes! A perspective on Africa's subdued research response to COVID-19 and a call for local scientific evidence. Environ. Res. 2021, 194, 110637. [CrossRef]

21. Adelle, C. The role of knowledge in food democracy. Politics Gov. 2019, 7, 214-223. [CrossRef]

22. Noubactep, C. A framework for technology development in Africa: The case of metallic iron (Fe ${ }^{0}$ ) water filters for safe drinking water provision. In Science and Biotechnology in Africa: Proceedings of a Conference on Scientific Advancement; Kapalanga, J., Raphael, D., Mutesa, L., Eds.; Cambridge Scholars Publishing: New Castle, UK, 2020; pp. 111-139.

23. Huang, Z.; Nya, E.L.; Rahman, M.A.; Mwamila, T.B.; Cao, V.; Gwenzi, W.; Noubactep, C. Integrated water resource management: Rethinking the contribution of rainwater harvesting. Sustainability 2021, 13, 8338. [CrossRef]

24. Pandey, D.N.; Gupta, A.; Anderson, D.M. Rainwater harvesting as an adaptation to climate change. Curr. Sci. $2003,85,46-59$.

25. Van Meter, K.J.; Basu, N.B.; Tate, E.; Wyckoff, J. Monsoon harvests: The living legacies of rainwater harvesting systems in South India. Environ. Sci. Technol. 2014, 48, 4217-4225. [CrossRef]

26. Chanan, A.P.; Vigneswaran, S.; Kandasamy, J.; Simmons, B. Wastewater management journey—From Indus Valley Civilisation to the twenty-first century. In Wastewater Reuse and Management; Sharma, S., Sanghi, R., Eds.; Springer: London, UK, 2013; pp. 3-17.

27. Rahman, A. Recent advances in modelling and implementation of rainwater harvesting systems towards sustainable development. Water 2017, 9, 959. [CrossRef]

28. Franco-Torres, M.; Rogers, B.C.; Harder, R. Articulating the new urban water paradigm. Crit. Rev. Environ. Sci. Technol. 2020. [CrossRef] 
29. Mahon, J.M.; Gill, L.W. Sustainability of novel water treatment technologies in developing countries: Lessons learned from research trials on a pilot continuous flow solar water disinfection system in rural Kenya. Dev. Eng. 2018, 3, 47-59. [CrossRef]

30. Ngai, T.K.K.; Murcott, S.; Shrestha, R.R.; Dangol, B.; Maharjan, M. Development and dissemination of Kanchan ${ }^{\text {TM }}$ Arsenic Filter in rural Nepal. Water Sci. Technol. Water Supply 2006, 6, 137-146. [CrossRef]

31. Shannon, M.A.; Bohn, P.W.; Elimelech, M.; Georgiadis, J.G.; Marinas, B.J.; Mayes, A.M. Science and technology for water purification in the coming decades. Nature 2008, 452, 301-310. [CrossRef]

32. Kearns, J.; Dickenson, E.; Aung, M.T.; Joseph, S.M.; Summers, S.R.; Knappe, D. Biochar water treatment for control of organic micropollutants with UVA surrogate monitoring. Environ. Eng. Sci. 2021, 38, 298-309. [CrossRef]

33. Hartigan, M. Help from above: Considering rainwater harvesting as an alternative to filtration (Innovations Case Discussion: SONO Filters). Innovations 2009, 4, 103-106. [CrossRef]

34. Noubactep, C.; Schöner, A.; Woafo, P. Metallic iron filters for universal access to safe drinking water. Clean Soil Air Water 2009, 37, 930-937. [CrossRef]

35. Kearns, J. Sustainable decentralized water treatment for rural and developing communities using locally generated biochar adsorbents. Water Cond. Purif. Int. 2012, 54, 7-12.

36. Noubactep, C. Beyond appropriateness and sustainability: Universal self-reliance in water supply. Sep. Sci. Appl. 2014, 34, 26-27.

37. Chaudhari, S.; Banerji, T.; Kumar, P.R. Domestic and community-scale arsenic removal technologies suitable for developing countries. In Water Reclamation and Sustainability; Ahuja, S., Ed.; Elsevier: Amsterdam, The Netherlands, 2014; pp. 155-182.

38. Peter-Varbanets, M.; Zurbrügg, C.; Swartz, C.; Pronk, W. Decentralized systems for potable water and the potential of membrane technology. Water Res. 2009, 43, 245-265. [CrossRef]

39. Gottinger, A.M.; Wild, D.J.; McMartin, D.; Moldovan, B.; Wang, D. Development of an iron-amended biofilter for removal of arsenic from rural Canadian prairie potable water. In Water Pollution X; Marinov, A.M., Brebbia, C.A., Eds.; WIT Press: Southampton, UK; Ashurst: London, UK, 2010; pp. 333-344.

40. Banerji, T.; Chaudhari, S. A cost-effective technology for arsenic removal: Case study of zerovalent iron-based IIT Bombay arsenic filter in West Bengal. In Water and Sanitation in the New Millennium; Nath, K., Sharma, V., Eds.; Springer: New Delhi, India, 2017.

41. Etmannski, T.R. Accounting for Sustainability in Bengal: Examining Arsenic Mitigation Technologies Using Process Analysis Method. Ph.D. Thesis, University of Oxford, Oxford, UK, 2014.

42. Kearns, J.P. Biochar Adsorbent for Control of Synthetic Organic Contaminants in Affordable Decentralized Water Treatment. Ph.D. Dissertation, University of Colorado, Boulder, CO, USA, 2016.

43. Tepong-Tsindé, R. Designing and Piloting a Household Filter for the Peri-Urban Population of Douala (Cameroon). Ph.D. Thesis, University of Göttingen, Göttingen, Germany, 2021.

44. Domènech, L. Rethinking water management: From centralised to decentralised water supply and sanitation models. Doc. d'Anàlisi Geogràfica 2011, 57, 293-310. [CrossRef]

45. Campos, L. Modelling and Simulation of the Biological and Physical Processes of Slow Sand Filtration. Ph.D. Dissertation, University of London, London, UK, 2002.

46. Kubare, M.; Haarhoff, J. Rational design of domestic biosand filters. J. Water Supply Res. Technol.—AQUA 2010, 59, 1-15. [CrossRef]

47. Adler, I.; Hudson-Edwards, K.A.; Campos, L.C. Converting rain into drinking water: Quality issues and technological advances. Water Sci. Technol. Water Supply 2011, 11, 659-667. [CrossRef]

48. McFarlane, K.; Harris, L.M. Small systems, big challenges: Review of small drinking water system governance. Environ. Rev. 2018, 26, 378-395. [CrossRef]

49. Prüss-Ustün, A.; Wolf, J.; Bartram, J.; Clasen, T.; Cumming, O.; Freeman, M.C.; Gordon, B.; Hunter, P.R.; Medlicott, K.; Johnston, R. Burden of disease from inadequate water, sanitation and hygiene for selected adverse health outcomes: An updated analysis with a focus on low- and middle-income countries. Int. J. Hyg. Environ. Health 2019, 222, 765-777. [CrossRef]

50. Weber-Shirk, M.L.; Dick, R.I. Bacterivory by a chrysophyte in slow sand filters. Water Res. 1999, 33, 631-638. [CrossRef]

51. Frechen, F.-B.; Exler, H.; Romaker, J.; Schier, W. Long-term behaviour of a gravity-driven dead end membrane filtration unit for potable water supply in cases of disasters. Water Sci. Technol. Water Supply 2011, 11, 39-44. [CrossRef]

52. Yang, H.; Hu, R.; Ndé-Tchoupé, A.I.; Gwenzi, W.; Ruppert, H.; Noubactep, C. Designing the next generation of Fe ${ }^{0}$-based filters for decentralized safe drinking water treatment. Processes 2020, 8, 745. [CrossRef]

53. Kearns, J.P.; Bentley, M.J.; Mokashi, P.; Redmon, J.H.; Levine, K. Underrepresented groups in WaSH-The overlooked role of chemical toxicants in water and health. J. Water Sanit. Hyg. Dev. 2019, 9, 786-793. [CrossRef]

54. Amrose, S.E.; Cherukumilli, K.; Wright, N.C. Chemical contamination of drinking water in resource-constrained settings: Global prevalence and piloted mitigation strategies. Annu. Rev. Environ. Resour. 2020, 45, 195-226. [CrossRef]

55. Gwenzi, W.; Chaukura, N.; Noubactep, C.; Mukome, F.N.D. Biochar-based water treatment systems as a potential low-cost and sustainable technology for clean water provision. J. Environ. Manag. 2017, 197, 732-749. [CrossRef]

56. Ndé-Tchoupé, A.I.; Crane, R.A.; Mwakabona, H.T.; Noubactep, C.; Njau, K.N. Technologies for decentralized fluoride removal: Testing metallic iron based filters. Water 2015, 7, 6750-6774. [CrossRef]

57. Lilje, J.; Mosler, H.-J. Continuation of health behaviors: Psychosocial factors sustaining drinking water chlorination in a longitudinal study from Chad. Sustainability 2016, 8, 1149. [CrossRef]

58. Nya, E.L. Access to Drinking Water and Sanitation in the Ndé Division (West Region/Cameroon). Ph.D. Thesis, University of Yaoundé I, Yaoundé, Cameroon, 2020. (In French). 
59. Kozicki, Z.A.; Baiyasi-Kozicki, S.J. The survival of mankind requires a Water Quality and Quantity Index (WQQI) and Water Applied Testing and Environmental Research (WATER) Centers. World Water Policy 2019, 5, 55-70. [CrossRef]

60. Murphy, H.M.; McBean, E.A.; Farahbakhsh, K. A critical evaluation of two point-of-use water treatment technologies: Can they provide water that meets WHO drinking water guidelines? J. Water Health 2010, 8, 611-630. [CrossRef] [PubMed]

61. Ogata, R.; Dangol, B.; Sakamoto, M. Sustainability assessment of long-term, widely used household Kanchan Arsenic Filters in Nepal. J. Environ. Sci. Health A 2020, 55, 517-527. [CrossRef] [PubMed]

62. Mueller, B.; Dangol, B.; Ngai, T.K.K.; Hug, S.J. Kanchan arsenic filters in the lowlands of Nepal: Mode of operation, arsenic removal, and future improvements. Environ. Geochem. Health 2021, 43, 375-389. [CrossRef]

63. Loo, S.-L.; Fane, A.G.; Krantz, W.B.; Lim, T.-T. Emergency water supply: A review of potential technologies and selection criteria. Water Res. 2012, 46, 3125-3151. [CrossRef]

64. Wydra, K.; Becker, P.; Aulich, H. Sustainable solutions for solar energy driven drinking water supply for rural settings in Sub-Saharan Africa: A case study of Nigeria. J. Photon. Energy 2019, 9, 043106. [CrossRef]

65. Martínez-Santos, P.; Martín-Loeches, M.; Díaz-Alcaide, S.; Danert, K. Manual borehole drilling as a cost-effective solution for drinking water access in low-income contexts. Water 2020, 12, 1981. [CrossRef]

66. Vivar, M.; Fuentes, M.; Pichel, N.; López-Vargas, A.; Rodrigo, M.J.; Srithar, K. Photovoltaic and solar disinfection technology meeting the needs of water and electricity of a typical household in developing countries: From a Solar Home System to a full-functional hybrid system. Sci. Total Environ. 2020, 747, 141082. [CrossRef]

67. Bradley, I.; Straub, A.; Maraccini, P.; Markazi, S.; Nguyen, T.H. Iron oxide amended biosand filters for virus removal. Water Res. 2011, 45, 4501-4510. [CrossRef]

68. Tepong-Tsindé, R.; Ndé-Tchoupé, A.I.; Noubactep, C.; Nassi, A.; Ruppert, H. Characterizing a newly designed steel-wool-based household filter for safe drinking water provision: Hydraulic conductivity and efficiency for pathogen removal. Processes 2019, 7, 966. [CrossRef]

69. Antia, D.D.J. Water treatment and desalination using the eco-materials n- $\mathrm{Fe}^{0}(\mathrm{ZVI}), \mathrm{n}-\mathrm{Fe}_{3} \mathrm{O}_{4}, \mathrm{n}-\mathrm{Fe}_{\mathrm{x}} \mathrm{O}_{\mathrm{y}} \mathrm{H}_{\mathrm{z}}\left[\mathrm{mH} \mathrm{H}_{2} \mathrm{O}\right]$, and $\mathrm{n}-$ $\mathrm{Fe}_{\mathrm{x}}$ [Cation $]_{\mathrm{n}} \mathrm{O}_{\mathrm{y}} \mathrm{H}_{\mathrm{z}}$ [Anion $]_{\mathrm{m}}\left[\mathrm{rH}_{2} \mathrm{O}\right]$. In Handbook of Nanomaterials and Nanocomposites for Energy and Environmental Applications; Kharissova, O.V., Martínez, L.M.T., Kharisov, B.I., Eds.; Springer Nature: Cham, Switzerland, 2020. [CrossRef]

70. Vandewalle, E.; Jepson, W. Mediating water governance: Point-of-use water filtration devices for low-income communities along the US-Mexico border. Geo Geog. Environ. 2015, 2, 107-121. [CrossRef]

71. Rook, J. Chlorination reactions of fulvic acids in natural waters. Environ. Sci. Technol. 1977, 11, 478-482. [CrossRef]

72. Kleijnen, R.G.; Knoben, B.G.M.; Hoofwijk, B.L.; Pol, D.G.J.; Heintges, G.H.L.; De Visser, J.F. The Chlorine Dilemma; Technical Report; Eindhoven University of Technology: Eindhoven, The Netherlands, 2011.

73. Sedlak, D.L.; von Gunten, U. The chlorine dilemma. Science 2011, 331, 42-43. [CrossRef]

74. Smeets, P.W.M.H.; Medema, G.J.; van Dijk, J.C. Engineering and Science The Dutch secret: How to provide safe drinking water without chlorine in the Netherlands. Drink. Water Eng. Sci. 2009, 2, 1-14. [CrossRef]

75. Reyneke, B.; Cloete, T.E.; Khan, S.; Khan, W. Rainwater harvesting solar pasteurization treatment systems for the provision of an alternative water source in peri-urban informal settlements. Environ. Sci. Water Res. Technol. 2018, 4, 291-302. [CrossRef]

76. Anderson, W. Purification of water by iron on a large scale. J. Soc. Arts 1883, 32, 963. [CrossRef]

77. Anderson, W. On the purification of water by agitation with iron and by sand filtration. J. Soc. Arts 1886, 35, 29-38. [CrossRef]

78. Campos, L.; Su, M.; Graham, N.; Smith, S. Biomass development in slow sand filters. Water Res. 2002, 36, 4543-4551. [CrossRef]

79. Lauderdale, R.A.; Emmons, A.H. A method for decontaminating small volumes of radioactive water. J. Am. Water Work. Assoc. 1951, 43, 327-331. [CrossRef]

80. Manz, D.H. BioSand Water Filter Technology; Manz Water Info: Calgary, AB, Canada, 2007.

81. Weber-Shirk, M. L Enhancing slow sand filter performance with an acid-soluble seston extract. Water Res. 2002, 36, 4753-4756. [CrossRef]

82. Weber-Shirk, M.L.; Chan, K.L. The role of aluminum in slow sand filtration. Water Res. 2007, 41, 1350-1354. [CrossRef]

83. Khan, A.H.; Rasul, S.B.; Munir, A.K.M.; Habibuddowla, M.; Alauddin, M.; Newaz, S.S.; Hussam, A. Appraisal of a simple arsenic removal method for groundwater of bangladesh. J. Environ. Sci. Health A 2000, 35, 1021-1041. [CrossRef]

84. Ngai, T.K.K.; Shrestha, R.R.; Dangol, B.; Maharjan, M.; Murcott, S.E. Design for sustainable development-Household drinking water filter for arsenic and pathogen treatment in Nepal. J. Environ. Sci. Health A 2007, 42, 1879-1888. [CrossRef] [PubMed]

85. Hussam, A.; Munir, A.K.M. A simple and effective arsenic filter based on composite iron matrix: Development and deployment studies for groundwater of Bangladesh. J. Environ. Sci. Health A 2007, 42, 1869-1878. [CrossRef] [PubMed]

86. Banerji, T.; Kalawapudi, K.; Salana, S.; Vijay, R. Review of processes controlling Arsenic retention and release in soils and sediments of Bengal basin and suitable iron based technologies for its removal. Groundw. Sustain. Dev. 2019, 8, 358-367. [CrossRef]

87. Noubactep, C.; Temgoua, E.; Rahman, M.A. Designing iron-amended biosand filters for decentralized safe drinking water provision. CLEAN-Soil Air Water 2012, 40, 798-807. [CrossRef]

88. Urfer, D.; Gigandet, J.; Störch, F. Slow sand filtration-New perspectives in the decentralized drinking water supply. AQUA GAS 2014, 1, 60-64. (In German)

89. Huang, Z.; Cao, V.; Nya, E.L.; Gwenzi, W.; Noubactep, C. Kanchan arsenic filters and the future of Fe ${ }^{0}$-based filtration systems for single household drinking water supply. Processes 2021, 9, 58. [CrossRef] 
90. Kearns, J.P.; Knappe, D.R.U.; Summers, R.S. Synthetic organic water contaminants in developing communities: An overlooked challenge addressed by adsorption with locally generated char. J. Water Sanit. Hyg. Dev. 2014, 4, 422. [CrossRef]

91. Gottinger, A.M.; McMartin, D.W.; Price, D.; Hanson, B. The effectiveness of slow sand filters to treat Canadian rural prairie water. Can. J. Civil Eng. 2011, 38, 455-463. [CrossRef]

92. Gottinger, A.M.; McMartin, D.W.; Wild, D.J.; Moldovan, B. Integration of zero valent iron sand beds into biological treatment systems for uranium removal from drinking water wells in rural Canada. Can. J. Civ. Eng. 2013, 40, 945-950. [CrossRef]

93. Jepson, W.; Vandewalle, E. Household water insecurity in the Global North: A study of rural and periurban settlements on the Texas-Mexico Border. Prof. Geogr. 2016, 68, 66-81. [CrossRef]

94. Haig, S.J.; Collins, G.; Davies, R.L.; Dorea, C.C.; Quince, C. Biological aspects of slow sand filtration: Past, present and future Water Sci. Technol. Water Supply 2011, 11, 468-472. [CrossRef]

95. Ali, I.; Gupta, V.K. Advances in water treatment by adsorption technology. Nat. Protoc. 2006, 1, 2661-2667. [CrossRef]

96. Ali, I. Water treatment by adsorption columns: Evaluation at ground level. Sep. Purif. Rev. 2014, 43, 175-205. [CrossRef]

97. Doula, M.K. Simultaneous removal of $\mathrm{Cu}, \mathrm{Mn}$ and $\mathrm{Zn}$ from drinking water with the use of clinoptilolite and its Fe-modified form. Water Res. 2009, 43, 3659-3672. [CrossRef] [PubMed]

98. Cao, V.; Ndé-Tchoupé, A.I.; Hu, R.; Gwenzi, W.; Noubactep, C. The mechanism of contaminant removal in $\mathrm{Fe}(0) / \mathrm{H}_{2} \mathrm{O}$ systems: The burden of a poor literature review. Chemosphere 2021, 280, 130614. [CrossRef]

99. Naseri, E.; Ndé-Tchoupé, A.I.; Mwakabona, H.T.; Nanseu-Njiki, C.P.; Noubactep, C.; Njau, K.N.; Wydra, K.D. Making Fe ${ }^{0}$-based filters a universal solution for safe drinking water provision. Sustainability 2017, 9, 1224. [CrossRef]

100. Noubactep, C. Metallic iron $\left(\mathrm{Fe}^{0}\right)$ provide possible solution to universal safe drinking water provision. J. Water Technol. Treat. Methods 2018, 1, 102. [CrossRef]

101. Dahi, E. Africa's U-Turn in Defluoridation Policy: From the Nalgonda Technique to Bone Char. Res. Rep. Fluoride 2016, 49 Pt 1 , 401-416.

102. Gwenzi, W.; Dunjana, N.; Pisa, C.; Tauro, T.; Nyamadzawo, G. Water quality and public health risks associated with roof rainwater harvesting systems for potable supply: Review and perspectives. Sustain. Water Qual. Ecol. 2015, 6, 107-118. [CrossRef]

103. Huisman, L.; Wood, W.E. Slow Sand Filtration; WHO: Geneva, Switzerland, 1974.

104. Buzunis, B.J. Intermittently Operated Slow Sand Filtration: A New Water Treatment Process. Unpublished. Master's Thesis, University of Calgary, Calgary, AB, Canada, 1995. [CrossRef]

105. Anggraini, A.K. Optimization of Slow Sand Filtration Design by Understanding the Influence of Operating Variables on the Suspended Solids Removal. Ph.D. Thesis, Karlsruher Instituts für Technologie, Karlsruhe, Germany, 2018.

106. Devonshire, E. The purification of water by means of metallic iron. J. Frankl. Inst. 1890, 129, 449-461. [CrossRef]

107. Manz, D.H. New Horizons for Slow Sand Filtration. In Proceedings of the Eleventh Canadian National Conference and Second Policy Forum on Drinking Water and the Biennial Conference of the Federal-Provincial-Territorial Committee on Drinking Water, Promoting Public Health Through Safe Drinking Water, Calgary, AB, Canada, 3-6 April 2004; pp. 682-692.

108. Urfer, D.; Fortier, S.P. Traitement décentralisé de l'eau potable-Kls ${ }^{\circledR}$ filter. ARPEA 2012, 252, 6-13.

109. Urfer, D. Use of bauxite for enhanced removal of bacteria in slow sand filters. Water Sci. Technol. Water Supply 2017, 17, 1007-1015. [CrossRef]

110. Noubactep, C. Metallic iron for safe drinking water worldwide. Chem. Eng. J. 2010, 165, 740-749. [CrossRef] 